\title{
Seasonal Variability of Discharge from Selected Springs in Central Europe
}

\author{
University of Lodz, Department of Hydrology and Water Management, 88 Narutowicza Str., 90-131 Lodz, Poland. \\ E-mail: moniek@geo.uni.lodz.pl
}

(Received 10 July 2014; Revised Accepted 23 April 2015)

The paper presents data on mean monthly discharges of nearly one hundred springs in Central Europe, measured over several years. Analyzes were based on discharge variability coefficients $(V, M, C v)$ and Markham's seasonality parameters: seasonality index and time of concentration. The results were interpreted with reference to three basic types of hydrogeological outflows: karst, fissure and porous. Seasonal spring discharge was found to be correlated with the spring altitude.

\section{Introduction}

Groundwater is a very important element of hydrogeological systems. Spring observations provide abundant information on the effects of actual rock conditions on the transformation of precipitation into groundwater discharges. Quantitative studies on the groundwater outflow discharges have been carried out in different countries for many years (Kriz 1973, Pulido-Bosch et al. 1995, Manga 1999, Milanovic 2002, Dolezal \& Kvitek 2004, Chelmicki et al. 2011). A large typological diversity of springs is reflected in variable types of outflow, even within the same hydrogeological unit. The springs of the Northern Calcareous Alps, supplied from fissured and karstified dolomites, have both outflows of high and stable discharge rates and variable and seasonal springs (Hilberg 2010). Automatization of discharge measurements and increasing their frequency (even on a basis of a few minutes) allows the identification of an increasing number of intermittent springs. Some examples of periodic springs are at Teufelskirche, with a discharge fluctuation period of ca $2.5 \mathrm{~h}$ (Kaiser 2005), or Gallusquelle (Swabian Alb, Germany - Heinz et al., 2006).

Despite the previous work, the regime of European springs is not yet sufficiently understood, particularly on a long time scale, and it is difficult to extrapolate the obtained results to a larger area. This is because there are few studies that present a cross-sectional approach and refer to a supra-regional scale (Kresic \& Stefanowic 2009).

A practical aspect of human interest in springs is their role in supplying drinking water. Many outflows, not only local ones, have been developed for the purposes of water supply. One of the largest examples of this type in Austria is the Kläffer Spring (Hochschwab Mountains), providing water supply to Vienna (Plan et al., 2010). Also, in Poland, two out of several large Tatra karst springs (Chelmicki et al. 2011), Bystre and Olczyskiej, have been developed to provide drinking water to Zakopane. The discharge of the piped springs has been measured regularly over a long period of time, thus allowing for an analysis of their seasonal variability.

\section{Materials and Methods}

Discharge of groundwater outflow is monitored in many countries of Central Europe by specialized teams. The measurements are undertaken independently of each other and at a different scales, mainly for the purpose of hydrological and hydrogeological analyses useful to national water management systems. For this reason, results of these measurements differ in, for example, the number of springs included in regular measurements, the time scale, frequency and methods of performing the measurements, as well as the approach to averaging (arithmetic mean or median) and the range of published data (Richtlinie ... 2009). A comparison of quantitative characteristics based this diverse information is difficult, but is possible.

This report takes account of mean monthly discharges for 93 springs in Austria (35 springs), Germany (8), Czech Republic (12), Slovakia (5) and Poland (33). In the case of 48 Czech, Slovak and Polish springs, monthly data are presented in the Hydrological Yearbooks (2004-2011), Hydrogeological Annual Reports (20032011), and an unpublished study by Fedorco (2007). It should be pointed out that monthly spring discharges are published in Polish annual reports as arithmetic means but in the Czech reports as medians. In the remaining 45 cases mean monthly discharges were calculated based on daily discharges (Austria: http://ehyd.gv.at/), daily or weekly discharges (Germany: http://www.gkd.bayern.de/grundwasser) and, in the case of two Polish lowland outflows, fortnightly discharge (database of Department of Hydrology and Water Resources University of Lodz). The maximum and minimum discharges were taken as the extremes of the measured values $(81.7 \%$ of the time series) and in the absence of specific data - as extreme monthly discharges (18.3\%).

Before analysis the measured data were selected and processed in terms of their representativeness and comparability. The time series were reviewed and possibly uniform study periods, covering 8 or 9 hydrological years, were selected. For the outflows in Austria and Germany the study period included the years 2003-2010, in the Czech Republic 2004-2011, and in Poland 2003-2011. Extending the series to cover earlier data was considered inexpedient, as this limited the number of springs that could be analyzed, thus the year 2002 was excluded because August of that year was characterized by abnormally abundant rainfall in some areas of Austria, Germany and the Czech 
Republic (Rudolf and Rapp, 2003). Due to limited availability of data for the springs in Slovakia, a nine year (1997-2005) measurement series was analyzed, corresponding in length to the most geographically similar series of spring discharge data in Poland. Out of the initial number of 145 outflows, 52 were rejected as not meeting the criterion of length, time convergence or series reliability. The subsequent analyses were performed for the time series in which the data gaps were smaller than $5 \%$ and were substituted based on linear trends.

The study area extends between $46^{\circ} 39^{\prime}$ and $51^{\circ} 55^{\prime} \mathrm{N}$ and $10^{\circ} 03^{\prime}$ and $22^{\circ} 40^{\prime} \mathrm{E}$. The springs are located within the catchments of three seas: the North Sea, the Black Sea, and the Baltic Sea. They also represent different morphological units. Some outflows are located within the structures created during Variscan orogeny (the Bohemian Massif, the Sudetes) and in the central part of the alpine structures (the Eastern Alps, the Western Carpathians), and some are within the region of Baltic glaciations (the Polish Lowland).

The catchments of the studied outflows are characterized by great lithological diversity. Their geological structure includes a great variety of rocks, from Paleozoic metamorphic igneous and sedimentary rocks, through Mesozoic carbonate and non-carbonate rocks, to Paleogene flysch deposits and Pleistocene glacial deposits. Based on the available

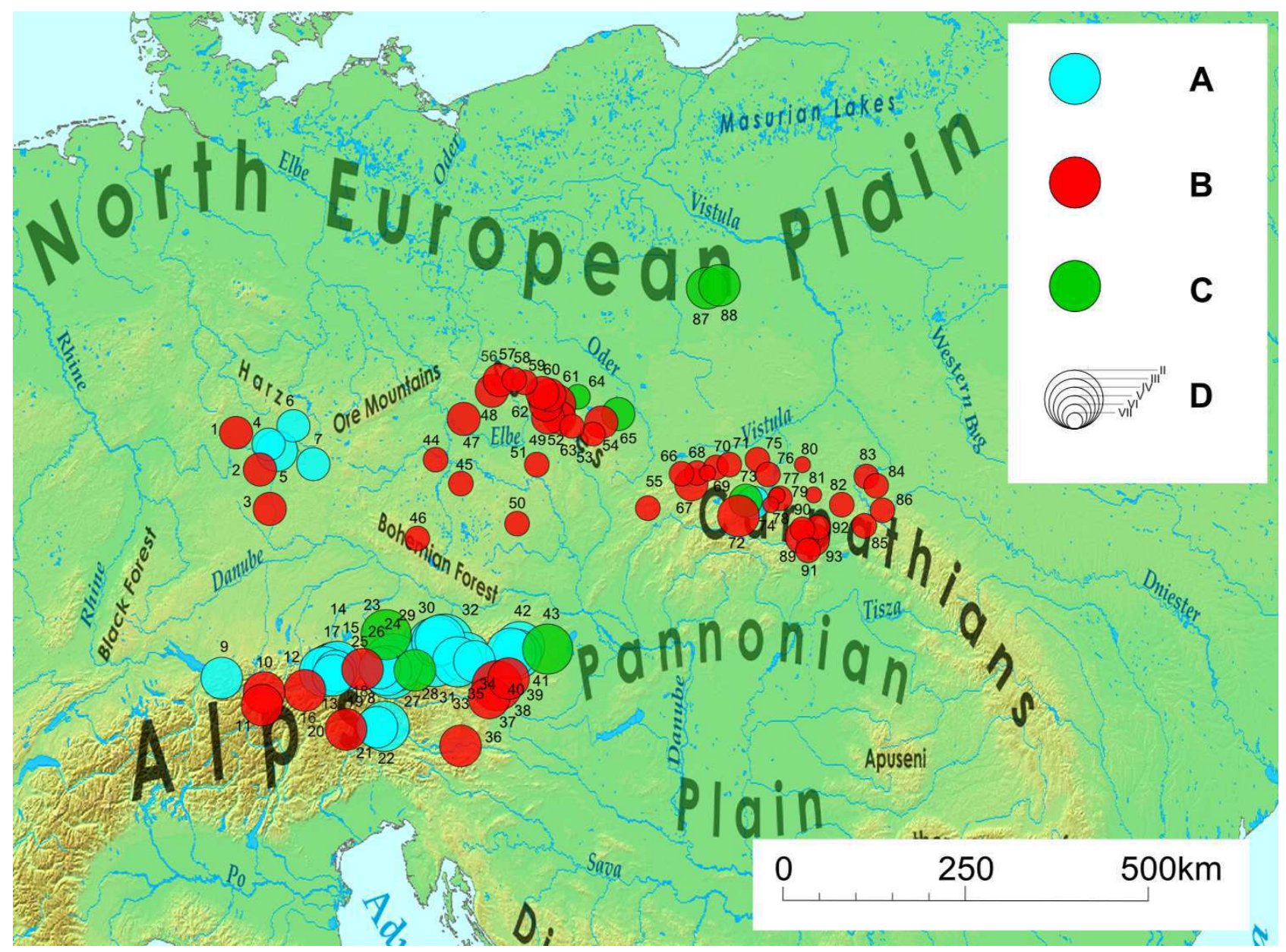

Figure 1. Location of observed springs according to their hydrogeological type: $A$ - karst, B - fissure, C - porous, D - mean outflow discharge $\left(Q_{m}\right)$ according to Meizer's classification (base map: http://en.wikipedia.org/wiki/Central_Europe, modified). List of springs: Germany: Salzloch (1), Hohenmuhle (2), Alexanderquellen (3), Staffelstein (4), Ellernbachquelle Rossdach (5), Weissbrunnen (6), Dorfquelle Adlholz (7), Strailach Quellen (8); Austria: Goldbachquelle (9), Brunauquelle (10), Ochsenbrunnquelle (11), Schwarzlackenquelle (12), Stubbachquelle (13), Katzensteigquelle (14), Muhlbacherquelle (15), Lacknerbrunnquelle (16), Blaue Quelle (17), Auebachquelle (18), Schreiende Brunnen (19), Gossenbachquelle (20), Schwarzbodenquelle (21), Moosbrunnquelle (22), Florianer Brunnbach (23), Gollinger Waterfall (24), Dachserfall (25), Waldbachursprung I (26), Odensee/Kaltwassertrichter (27), Sagtumpel (28), Brunnental (29), Teufelskirche I (30), Piessling Ursprung (31), Rettenbachquelle (32), Schonebequelle (33), Wassermannsloch (34), Schwabeltalquelle (35), Draurainquelle (36), Reithbachquelle (37), Hammerbachquelle (38), Brunnaderquelle (39), Rosslochquelle (40), Siebenquellen I (41), Wasseralmquelle (42), Fischa-Dagnitz, Quelle (43); Czech Republic: Voznice (44), Hermanicky (45), Novy Swet (46), Strizowice (47), Dolanky/Bezednice (48), Ostromer (49), Mrakotin/Krizova Louka (50), Hamry nad Sazavou (51), Hronov (52), Novy Malin (53), Zlate Hory (54), Bila (55); Poland: Czerniawa (56), Karpacz (57), Kowary-Wojkow (58), Dobromysl (59), Kowalowa (60), Szczytna Slaska (61), Mloty (62), Rozanka (63), Czernczyce (64), Rudziczka (65), Ustron-Dobka (66), Kamesznica (67), Czernichow (68), Ponikiew (69), Babica (70), Stroza (71), Zakopane-Capki (72), Debno (73), Falsztyn (74), Mlynne (75), Zawadka-Rojowka (76), Rytro-Roztoka (77), Jaworki-Biala Woda (78), Wierchomla (79), Jodlowka Tuchowska (80), Katy (81), Radoszyce (82), Sanok-Olchowce (83), Bezmiechowa Gora (84), Wetlina (85), Dwerniczek (86), Rosanow (87), Ciosny (88); Slovakia: Ruska Nova Ves (89), Okruzna (90), Lucina (91), Hermanovce nad Toplou (92), Rudlov (93). 
data, the aquifer type was established for each spring, but the great geological diversity prevents a detailed interpretation of their role in supplying outflows.

For this reason, it was necessary to limit the aquifer features only to those properties that are relevant from the hydrogeological point of view. Therefore the investigated springs were classified into three basic hydrogeological types (Pfleiderer et al. 2006; Christe, 2013). Twenty nine springs were identified as karst (limestone, dolomite), 56 as fissures (sandstone, marl, shale, crystalline, volcanic, metamorphic rocks) and 8 as porous (gravels, sands, saprolite) Figure 1.

Most of the investigated springs are not used for the economic purposes. They supply numerous creeks, streams and rivers. Examples of well-known and frequently visited sites among the analyzed springs include Gollinger Waterfall, falling into the river Salzach, or Salzloch spring, the outflow of the south stream constituting the beginning of the Franconian Saale. However, some springs with regular discharge monitoring are piped for the purpose of local water supply, e.g. Waldbachursprung I, Auebachquelle, Stubbachquelle, Wasseralmquelle or Schwarzbodenquelle (Eybl, 2005).

The analysis of spring discharge variability was based on three coefficients: (Kriz, 1973; Kresic and Stefanowic, 2009):

$$
\begin{aligned}
& V=\frac{Q_{\text {max }}-Q_{\text {min }}}{Q_{m}} \cdot 100 \% \\
& M=\frac{Q_{\text {max }}}{Q_{\text {min }}} \\
& C v=\frac{S D}{Q_{m}} \cdot 100 \%
\end{aligned}
$$

where:

V, M, Cv - coefficients of variation (according to Meinzer (1923), Maillete (1905) and Cv ratio)

$Q_{\max }, Q_{m}, Q_{\min }-$ maximum, mean and minimum monthly discharge;

$S D$ - standard deviation for mean monthly discharge.

The seasonal discharges of the springs were analyzed using a vector method proposed by Ch. G. Markham (1970) for assessing the seasonality of precipitation (Markham's vector method). Adopting this method, we assumed that daily spring discharges are vectors $\vec{r}$ $(1,2, \ldots, 365)$, the length of which is specified by the discharge value and the direction determined by the angle $\alpha_{i}=(360 . i) / 365$, where $i$ $=1,2, \ldots, 365$-number of days from the beginning of a hydrological year. A resultant of 365 vectors $\overrightarrow{r_{i}}$ is $\vec{R}$ vector of the length $|\mathrm{R}|$ and the direction $\omega$. Adaptation of seasonality parameters to monthly data requires some transformations. The angle $\omega$ indicates the time of discharge concentration in a hydrological year:

$$
\omega=\operatorname{arctg} \frac{\sum_{n=1}^{12}\left|\vec{r}_{n}\right| \cos \alpha_{n}}{\sum_{n=1}^{12}\left|\overrightarrow{\mathrm{r}}_{\mathrm{n}}\right| \sin \alpha_{n}}
$$

where:

$\omega$ - angle indicating the time of concentration;

$n=1,2 \ldots 12$ (months);

$\vec{r}_{n}=$ vector identified as a mean outflow discharge in the next month;

$\alpha_{n}$ - angle defining the direction of the vector $\vec{r}_{n}$.
The date of an outflow concentration $(\mathrm{K})$ is calculated by adding the number of days:

$$
i=\omega \frac{365}{360}
$$

to the date of the beginning of a hydrological year.

Seasonality index is expressed by the formula:

$I S_{m}=\frac{\left|\vec{R}_{\mathrm{m}}\right|}{\sum_{\mathrm{n}=1}^{12}\left|\vec{r}_{n}\right|} \cdot 100 \%$

where:

$I S_{m}-$ seasonality index

$n=1,2 \ldots 12$ (months);

$\vec{r}_{n}=$ vector identified as a mean outflow discharge in the next month;

$\vec{R}_{\mathrm{m}}$ - a resultant vector determined based on 12 vectors as their geometric mean:

$$
\left|\vec{R}_{\mathrm{m}}\right|=\sqrt{\left(\sum_{\mathrm{n}=1}^{12}\left(\left|\vec{r}_{n}\right| \cos \alpha_{\mathrm{n}}\right)\right)^{2}+\left(\sum_{\mathrm{n}=1}^{12}\left(\left|\vec{r}_{n}\right| \sin \alpha_{\mathrm{n}}\right)\right)^{2}}
$$

The values of the seasonality index range from 0 to $100 \%$. The highest values are recorded for outflows for which the discharges were clearly concentrated in a specific month. The lowest values usually reflect an outflow evenly distributed over a year or a situation when the outflow is concentrated in two opposite seasons (months), for example, in April and October.

\section{Spring discharge}

The mean monthly discharge of the investigated outflows was variable (Table 1). The mean discharge in the analyzed multi-year period ranged from $3019 \mathrm{dm}^{3} \cdot \mathrm{s}^{-1}$ (Waldbachursprung I) to less than $0.1 \mathrm{dm}^{3} \cdot \mathrm{s}^{-1}$ (5 Carpathian outflows). The second discharge class according to O. Meizer (in Metric Units, Kresic 2007) comprised five springs, the third -16 , the fourth -20 , the fifth -21 , the sixth - 26, and the seventh - 5. Maximum discharge for the largest outflows exceeded $10 \mathrm{~m}^{3} \cdot \mathrm{s}^{-1}$ (Piessling Ursprung $-33.3 \mathrm{~m}^{3} \cdot \mathrm{s}^{-1}$, Gollinger Waterfall $-31.4 \mathrm{~m}^{3} \cdot \mathrm{s}^{-1}$, Teufelskirche $-24.6 \mathrm{~m}^{3} \cdot \mathrm{s}^{-1}$, Rettenbachquelle $-18.8 \mathrm{~m}^{3} \cdot \mathrm{s}^{-1}$, Waldbachursprung $-17.4 \mathrm{~m}^{3} \cdot \mathrm{s}^{-1}$ ). Minimum discharge values ranged from $277.4 \mathrm{dm}^{3} \cdot \mathrm{s}^{-1}$ to just $10.5 \mathrm{dm}^{3} \cdot \mathrm{s}^{-1}$.

The discharge was obviously highest in the case of karst springs - the mean discharge for the smallest one exceeded $1 \mathrm{dm}^{3} \cdot \mathrm{s}^{-1}$, and mean outflow discharge in this group was nearly $200 \mathrm{dm}^{3} \cdot \mathrm{s}^{-1}$. Mean discharges above $100 \mathrm{dm}^{3} \cdot \mathrm{s}^{-1}$ were observed in as many as $62 \%$ outflows. The mean discharge of the porous springs was a few times lower, amounting to $26.3 \mathrm{dm}^{3} \cdot \mathrm{s}^{-1}$. The most efficient porous outflow was Florianer Brunnbach, with a mean discharge of $896.4 \mathrm{dm}^{3} \cdot \mathrm{s}^{-1}$. The fissure springs turned out to be the least productive. Their mean discharge was only $1.0 \mathrm{dm}^{3} \cdot \mathrm{s}^{-1}$, and for only 11 of them $(20 \%)$ did the discharge exceeded $10 \mathrm{dm}^{3} \cdot \mathrm{s}^{-1}$. The most productive outflow in the group of fissure springs was Hammerbachquelle $\left(Q_{m}=177.6\right.$ $\left.\mathrm{dm}^{3} \cdot \mathrm{s}^{-1}\right)$.

The greatest irregularity of discharge was observed for fissure springs. The median coefficient of variation $\mathrm{Cv}_{\text {me }}$ in this group was close to $60 \%$. Among 11 periodic springs, 9 were of a fissure type (16\% of their total number). The karst spring group included only two periodic outflows (Brunnental, Schonebenquelle), and although the discharge coefficient of variation was similar to the fissure outflows 
Table 1. The characteristics of mean monthly spring discharge in the years 2003-2010

\begin{tabular}{lccccccccccccc}
\hline Type & Number & $\mathrm{Q}_{\mathrm{me}}$ & $\mathrm{Q}_{\max }$ & $\mathrm{Q}_{\min }$ & $\mathrm{Cv}_{\mathrm{me}}$ & $\mathrm{Cv}_{\max }$ & $\mathrm{Cv}_{\min }$ & $\mathrm{M}_{\text {me }}$ & $\mathrm{M}_{\max }$ & $\mathrm{M}_{\min }$ & $\mathrm{V}_{\text {me }}$ & $\mathrm{V}_{\max }$ & $\mathrm{V}_{\min }$ \\
\hline Karst & 29 & 199.2 & 3019.0 & 1.11 & 62.5 & 100.4 & 6.5 & 16.2 & 1657 & 2.5 & 674.0 & 2464.2 & 90.7 \\
Fissure & 56 & 1.0 & 177.6 & 0.06 & 59.6 & 496.9 & 4.1 & 9.4 & 500 & 1.3 & 641.0 & 5963.1 & 27.3 \\
Porous & 8 & 26.3 & 896.4 & 0.50 & 17.9 & 90.2 & 3.5 & 2.9 & 44 & 1.2 & 278.8 & 1369.2 & 16.1 \\
\hline
\end{tabular}

Spring discharge $\left[\mathrm{dm}^{3} \cdot \mathrm{s}^{-1}\right]: \mathrm{Q}_{\mathrm{me}}-$ median, $\mathrm{Q}_{\max }-$ maximum, $\mathrm{Q}_{\min }-$ minimum; variability index $[\%]: \mathrm{Cv}_{\operatorname{me}}-\mathrm{median}, \mathrm{Cv}_{\max }-\operatorname{maximum}$, $\mathrm{CV}_{\min }-$ minimum; Maillete' variability index: $\mathrm{M}_{\mathrm{me}}-$ median, $\mathrm{M}_{\max }-$ maximum, $\mathrm{M}_{\min }-$ minimum; Meinzer variability index: $\mathrm{V}_{\mathrm{me}}-\mathrm{median}$, $\mathrm{V}_{\max }-$ maximum, $\mathrm{V}_{\min }-$ minimum.

(mean $\mathrm{Cv}=62.5 \%$ ), the range was fairly wide, from 6.5 to $100.4 \%$. All porous springs were permanent outflows and their mean discharge coefficient of variation was $17.9 \%$. One of them was the most regular spring in Czernczyce $\left(\mathrm{Q}_{\mathrm{m}}=0.5 \mathrm{dm}^{3} \cdot \mathrm{s}^{-1}\right)$, for which the discharge coefficient of variation was only $3.5 \%$.

The least regular discharge was recorded for a small $\left(\mathrm{Q}_{\mathrm{m}}=0.27\right.$ $\mathrm{dm}^{3} \cdot \mathrm{s}^{-1}$ ) fissure spring in Karpacz, the Cv of which $497 \%$. However, this does not mean that large springs are characterized by greater regularity of the discharge. The discharge coefficient of irregularity of the largest spring Waldbachursprung I was $100 \%$. Nevertheless, the relationship between the spring discharge irregularity and its amount was statistically insignificant. A clear positive correlation $(r=0.4)$ can be observed only in the group of outflows with a discharge exceeding $10 \mathrm{dm}^{3} \cdot \mathrm{s}^{-1}$. This means that the largest springs are usually characterized by high variability of discharge $(\mathrm{Cv}=80-100 \%)$, but the variability is also considerable for smaller outflows - mean $\mathrm{Cv}$ for springs with a discharge $<1 \mathrm{dm}^{3} \cdot \mathrm{s}^{-1}$ was $76 \%$. The lowest irregularity was found in the group of springs belonging to the fourth class of discharge according to $\mathrm{O}$. Meinzer $(\mathrm{Cv}=40 \%) . \mathrm{Cv}<10 \%$ was recorded for only 4 springs, and this was not related to their discharge, but to a gravel or sand structure of the aquifer.

The variability of multi-year discharges is different for springs of different hydrogeological types. The most variable multi-year discharge among the permanent outflows was observed in karst springs, where the average Maillete variability index was $M=16.0$, and Meinzer variability index was $\mathrm{V}_{\mathrm{me}}=674.0 \%$ (Table 1). The largest spring belonging to this group - Waldbachursprung I, was also the most variable - the coefficient of variation was as high as $1657(\mathrm{~V}=576 \%)$. Very high variability was also found for the discharge of the Gollinger Waterfall $-\mathrm{V}=2464.2 \%$ ( $\mathrm{M}=708)$. However, even in the karst environment, there are springs with low discharge irregularity. The Maillete variability index calculated for the Katzensteigquellen spring for the years 2003-2010 was 3.8; almost the same as in the period 1993-2004 analyzed by Mair (2005) which was $M=3.7$. The coefficients of variation are only indirectly related to the hydrogeological type of outflow, and they mainly depend on the water supply capacity of the aquifer. For comparison, the Maillete variability index for the discharge of large karst springs in Bulgaria ranged from 8 to 180 and it was concluded that the outflows with lower discharge variability were characterized by longer system "memory" (PulidoBosch et al. 1995).

Taking into account the Maillete variability index (M), the analyzed group of springs was comprised of 30 highly variable outflows ( $M>50$, including 11 periodically disappearing), 21 variable outflows $(\mathrm{M} \div 10.50)$, 36 hardly variable outflows $(\mathrm{M}=2 \div 10)$, and only 6 constant outflows $(M=1 \div 2)$. Very variable springs usually included fissure springs (36\% of their number) and karst springs (34\%). As many as $87 \%$ of porous springs were of hardly variable or constant character. The most regular spring was a small Czernczyce spring $\left(\mathrm{Q}_{\mathrm{m}}=0.5 \mathrm{dm}^{3} \cdot \mathrm{s}^{-1}\right)$ with $\mathrm{M}=1.2$.

In contrast, the most irregular spring, in terms of Meinzer variability index $(\mathrm{V})$, was a small $\left(\mathrm{Q}_{\mathrm{m}}=0.27 \mathrm{dm}^{3} \cdot \mathrm{s}^{-1}\right)$ periodic fissure spring in Karpacz ( $\mathrm{V}=5963 \%)$. Only one spring (Czernczyce) can be classified as permanent $(\mathrm{V}=16.1 \%)$ and 8 as variable $(\mathrm{V}<100 \%)$ : one karst - Muhlbacherquelle $(\mathrm{V}=90.7 \%), 3$ porous and 5 fissure springs. The other springs (90\% of total number of outflows) were highly variable springs (Table 2).

\section{Spring regime}

Changes in a spring discharge during a year depend on the seasonal distribution of supply of the drained aquifer. Typical regimes of alpine springs involve glacial, glacio-nival, and nival-pluvial regimes (Christe 2013). Higher parts of the Alps are dominated by simple

Table 2. Range of the variability indexes of presented springs.

\begin{tabular}{|c|c|c|c|c|c|c|}
\hline Class & $\mathrm{V}[\%]$ & Spring numbers & M [-] & Spring numbers & $\mathrm{Cv}[\%]$ & Spring numbers \\
\hline Highlyvariable & - & - & $>50$ & $\begin{array}{l}20,24,26,28-34,41,46,53 \\
56-57,59-60,66-69,72,75-78, \\
82,86,91,93\end{array}$ & $>60$ & $\begin{array}{l}2,4,12,18-20,24-26,28-35, \\
41,46-47,51,53,56-60,66-69, \\
71-73,75-78,80,86,89,91-93\end{array}$ \\
\hline Variable & $>100$ & $\begin{array}{l}2,4,14,17-43,45-51 \\
53-60,62-63,66-86 \\
88-93\end{array}$ & $10-50$ & $\begin{array}{l}2,4-5,12,18-19,25,35,38, \\
40,42,51,58,71,73-74,80, \\
84-85,89,92\end{array}$ & $40-60$ & $\begin{array}{l}7,11,40,42,45,48,55,74 \\
79,82,85,90\end{array}$ \\
\hline Meanvariable & $25-100$ & $\begin{array}{l}1,3,15-16,44,52,61 \\
65,87\end{array}$ & $2-10$ & $\begin{array}{l}1,6-11,13-17,21-23,27,36-37 \\
39,43,45,47-50,54-55,62-63 \\
70,79,81,83,87-88,90\end{array}$ & $20-40$ & $\begin{array}{l}5-6,8,10,13-14,21-22,27, \\
36-38,49-50,54,62-63,70, \\
81,83,84\end{array}$ \\
\hline $\begin{array}{l}\text { Smallvariable } \\
\text { (constant) }\end{array}$ & $<25$ & 64 & $1-2$ & $3,44,52,61,64-65$ & $0-20$ & $\begin{array}{l}1,3,9,15-17,23,39,43-44 \\
52,61,64-65,87-88\end{array}$ \\
\hline
\end{tabular}

V - Meinzer variability index, M - Maillete' variability index, $\mathrm{Cv}$ - variability index; Spring numbers in accordance with Figure 1. 
regimes: glacial and snowmelt, and the borders and the eastern part are dominated by complex regimes: snowmelt-rainfall and rainfallsnowmelt (Bard et al. 2011).

When mean monthly spring discharge in the analyzed period was taken into account, the highest discharge was usually observed in April (25 outflows), May (22) and March (18), while the lowest occurred in February (26), December (17) and November (16). The highest mean monthly discharge was never observed in October, and the lowest was never recorded between May and July. The regime of most investigated springs is complex (57.5\% of all springs), and nival supply clearly dominates over precipitation supply (49\% vs. $8.5 \%$ ). Kläffer Spring, whose mean discharge was $5146 \mathrm{dm}^{3} \cdot \mathrm{s}^{-1}$ (in the years 1995-2006) and $\mathrm{M}=116$, can also be classified to this type of outflows. This outflow is characterized by a typical snowmelt-rainfall regime, with the largest multi-year discharge observed in May, the second weaker maximum in August, and the minimum in February. The highest observed discharge was as high as $45 \mathrm{~m}^{3} \cdot \mathrm{s}^{-1}$ (Plan et al. 2010).

Nival supply dominates also among the springs with simple regimes, as a culmination of the discharge in $33 \%$ of these outflows was observed in the spring months. Maximum discharges in $8.5 \%$ of these springs occur in the summer months, but in some of them the discharge is a result of snowmelt. This can be shifted with respect to supply by even a few months, as the aquifers of these springs are composed of non-carbonate structures. This is why the snowmelt (nival) supply may prevail. The dual nature of the runoff was observed at Wasseralmquelle. Water from melted snow reached the spring through "fast channels", while the base runoff was formed by water flowing in the fissure-porous system (Rank et al. 2006).

According to Birk and Wagner (2011), a heavy flood in August 2005 changed the conditions of water circulation in karst hydrogeological systems, resulting in much faster recession of discharge. However, this phenomenon did not affect the mean monthly discharge of the alpine springs. Their total discharge was then only $4 \%$ higher than the multi-year mean for this month. Only one spring achieved the highest mean monthly discharge in August (Hammerbachquelle), and three in September 2005 (Brunnaderquelle, Katzensteigquelle, Muhlbacherquelle). In numerous Carpathian springs the highest mean discharge was reported in May (8) or June (3) 2010, during a large flood in the Vistula catchment. The second group also consisted of two Sudeten springs: Zlate Hory and KowaryWojkow.

The month with the highest water supply was May 2009, when the total mean discharge of all analyzed springs was $44.4 \mathrm{~m}^{3} \cdot \mathrm{s}^{-1}$. The driest month was December 2003 with total mean monthly outflow discharge just below $5.1 \mathrm{~m}^{3} \cdot \mathrm{s}^{-1}$.

The correlations between spring discharges provide many examples of local interrelations. In the Tatra karst springs, with a pluvio-nival regime, the daily discharge correlation coefficients were within the range of 0.57-0.97 (Barczyk 2003).

The strongest correlation among the investigated springs was found for mean monthly discharge of Odensee/Kaltwassertrichter and Piessling Ursprung (Pearson's correlation coefficient r=0.97), even though they represent different hydrogeological spring types: porous and karst respectively. Their discharge was highly synchronized, as these springs are located less than $50 \mathrm{~km}$ from each other. However, in most cases, the regional relationships are dominated by the precipitation transformation method determined by the hydrogeological type of outflow. It is worth noticing that the mean significant correlation coefficient is the highest in the case of karst springs $(\mathrm{r}=0.64)$. The discharge of fissure and porous springs is somewhat less correlated with the other outflows $(r=0.57, r=0.56$, respectively). The highest mean correlation coefficient ( $\mathrm{r}=0.72)$ was achieved for the Odensee/Kaltwassertrichter spring. The highest number of significant correlation coefficients was obtained for the following springs: Rosslochquelle (53 coefficients), Rettenbachquelle, Hronov and Mlynne (52), and Schwabeltalquelle and KowaryWojkow (50). In contrast, the most "outstanding" spring in terms of discharge course was Alexanderquellen, for which no significant correlations with any other outflow were found.

\section{Seasonal variability of the discharge}

The average seasonality index for the fissure springs is the same as calculated for the total spring population and it amounts to 21.7 (Table 3). A slightly higher mean seasonality index was found in the karst springs (27.5), and the seasonality of the porous springs was four times lower (6.1).

Table 3. Mean seasonality index and time of discharge concentration of the springs in the years 2003-2010.

\begin{tabular}{lllllll}
\hline Type & $\mathrm{IS}_{\mathrm{m}}$ & $\mathrm{IS}_{\max }$ & $\mathrm{IS}_{\min }$ & $\mathrm{K}_{\mathrm{m}}$ & $\mathrm{K}_{\max }$ & $\mathrm{K}_{\min }$ \\
\hline Karst & 27.5 & 60.8 & 2.4 & May 20 & July 10 & March 5 \\
Fissure & 21.7 & 69.1 & 1.1 & April 29 & July 16 & March 3 \\
Porous & 6.1 & 22.8 & 1.2 & May 5 & June 13 & March 16 \\
\hline
\end{tabular}

Seasonality index [\%]:IS $\mathrm{m}_{\mathrm{m}}-$ median, $\mathrm{IS}_{\max }-$ maximum, $\mathrm{IS}_{\min }-$ minimum; date of discharge concentration [day]: $\mathrm{K}_{\mathrm{m}}-$ median, $\mathrm{K}_{\max }-$ maximum, $\mathrm{K}_{\min }$ - minimum.

The highest seasonality index in the group of the karst springs was observed for the largest and most variable spring Waldbachursprung I (60.8\%). The lowest seasonality index $(2.4 \%)$ was obtained for a medium size Goldbachquelle spring with a discharge of $57 \mathrm{dm}^{3} \cdot \mathrm{s}^{-1}$, located at $1000 \mathrm{~m}$ a.s.l. In the analyzed period, the discharge varied from 46.6 to $158.3 \mathrm{dm}^{3} \cdot \mathrm{s}^{-1}$, and the Maillete variability index $(\mathrm{M})$ reached 3.4 .

The lowest seasonality index (1.1\%) among the fissure outflows was observed for the Alexanderquellen springs, involving a few outflows with the total mean discharge of $3.85 \mathrm{dm}^{3} \cdot \mathrm{s}^{-1}$. A very low seasonality suggests almost constant discharges throughout the year, and it was confirmed that these can be classified into the constant outflow group $(M=1.3)$. The highest seasonal variability of discharge (69.1\%) was recorded for Gossenbachquelle spring $\left(Q_{m}=17.6 \mathrm{dm}^{3} \cdot \mathrm{s}^{-1}\right)$ located at the highest altitude of any of the springs studied (2007 $\mathrm{m}$ a.s.1.). It is a periodic spring with typical a pluvial supply, as it never functions in February and March, and the nodischarge periods often last from December through April. Its maximum discharge, amounting to $218 \mathrm{dm}^{3} \cdot \mathrm{s}^{-1}$, was recorded in June 2004.

The seasonality index for porous springs is low and in nearly all cases was below the mean value for all the studied springs. The $10 \%$ value was exceeded in only two cases. The highest index of seasonality (IS $\mathrm{m}_{\mathrm{m}}=22.8 \%$ ) was observed for the Carpathian spring Debno, supplied by gravel-sand valley deposits. Its mean discharge was $9.0 \mathrm{dm}^{3} \cdot \mathrm{s}^{-1}$ and it was characterized by considerable variability $(\mathrm{Cv}=90.2 \%$, $\mathrm{M}=43.7)$. The lowest index of seasonality in this group was recorded for the most stable spring in Czernczyce.

The date of the spring runoff concentration is usually May 3rd. It 
first occurs in the fissure springs (April 29th) - about a week earlier than in the porous springs (May 5th), and three weeks earlier than in the karst springs (May 20th). The springs differ also in the time span of the discharge concentration date - the difference between the earliest and latest time of concentration observed in the group of fissure springs is 4.5 months. The earliest concentration time (March 3rd) was recorded for the ascending Bezednice spring in Dolanky $\left(\mathrm{Q}_{\mathrm{m}}=\right.$ $\left.8 \mathrm{dm}^{3} \cdot \mathrm{s}^{-1}\right)$, supplied from Cretaceous sandstones. The latest concentration time (July 16th) was observed for Ochsenbrunnquelle spring $\left(\mathrm{Q}_{\mathrm{m}}=88 \mathrm{dm}^{3} \cdot \mathrm{s}^{-1}\right)$, located at $1408 \mathrm{~m}$ a.s.l. Interestingly, both springs are characterized by an almost identical index of seasonality $\left(\mathrm{IS}_{\mathrm{m}} 26.7 \%\right.$ and $27.3 \%$, respectively) and a very similar Maillete variability index ( $\mathrm{M}=7.8$ and $\mathrm{M}=7.3$, respectively).

The time span for the discharge concentration date for the karst springs is only slightly lower than for the fissure springs and it is just over four months. The earliest concentration time (March 5th) was recorded for Weissbrunnen spring $\left(\mathrm{Q}_{\mathrm{m}}=7 \mathrm{dm}^{3} \cdot \mathrm{s}^{-1}\right)$, the lowest karst outflow ( $\mathrm{H}=339.9 \mathrm{~m}$ a.s.1.), and the latest concentration time (July 10) was observed for Waldbachursprung I spring.

The shortest, only a 3-month span in the concentration time, was typical of the porous springs. The concentration time in this group occured latest - at a regular spring in Czernczyce it takes place on March $16^{\text {th }}$, while the last spring in this group is the most highly located spring ( $\mathrm{H}=770 \mathrm{~m}$ a.s.l.) Odensee/Kaltwassertrichter (June 13), with mean discharge of $30.5 \mathrm{dm}^{3} \cdot \mathrm{s}^{-1}$.

The most typical values of the seasonality index and concentration time, equal to the means of all the outflows, were found for a fissure spring called Krizova Louka in Mrakotin $\left(\mathrm{Q}_{\mathrm{m}}=0.6 \mathrm{dm}^{3} \cdot \mathrm{s}^{-1}\right)$. The variability of its discharge $(\mathrm{M}=6.9)$ was not very different from the mean value calculated for all permanent outflows (9.6). However, it could not be considered representative for the other springs, as they showed high seasonal variability (Figure 2). The groups of karst and fissure springs included many examples where the seasonality index and time of discharge concentration were considerably below or above the average. Only for the porous springs, where the aquifer stabilizes the supply dynamics was the seasonality index below average. However, the lowest seasonality index was found in lowland springs at Rosanow $\left(\mathrm{Q}_{\mathrm{m}}=45.0 \mathrm{dm}^{3} \cdot \mathrm{s}^{-1}\right)$ and Ciosny $\left(\mathrm{Q}_{\mathrm{m}}=22.0 \mathrm{dm}^{3} \cdot \mathrm{s}^{-1}\right)$, supplied from sand and gravel outwash deposits. Considerable aquifer storativity results in low variability of the annual discharge pattern, and the lowest seasonality index was found in the porous

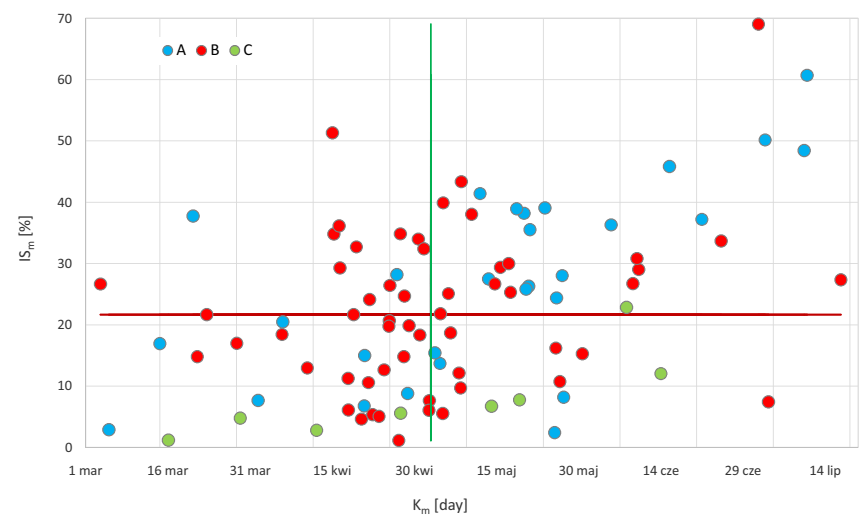

Figure 2. Seasonality index $\left(I S_{m}\right)$ and date of discharge concentration $\left(K_{m}\right)$ according to hydrogeological types of springs: $A$ - karst, B - fissure, $C$ - porous. The lines indicate mean values (median). springs: Rudziczka $\left(\mathrm{Q}_{\mathrm{m}}=1.7 \mathrm{dm}^{3} \cdot \mathrm{s}^{-1}\right)$ and, as already mentioned, Czernczyce.

Although the time of spring discharge concentration does not depend on its seasonality index, a significant positive correlation between these factors was found in the karst springs ( $r=0.66)$ and porous springs $(\mathrm{r}=0.80)$. This means that the springs with higher seasonality index, in which the runoff is more "concentrated" in a specific time of a year, are characterized by later peak discharge dates (Figure 3). This confirms a key role of the pluvial supply of the outflows and the spatial range of their supply zone. An example of this situation is the Gollinger Waterfall where, the discharge is characterized by a relatively high seasonality $\left(\mathrm{IS}_{\mathrm{m}}=50.2 \%\right)$ and late concentration time (July 2). This outflow is located at about $620 \mathrm{~m}$ a.s.l., but it provides drainage for a strongly karstified Hoher Göll massif, the peaks of which exceed $2300 \mathrm{~m}$ a.s.l.

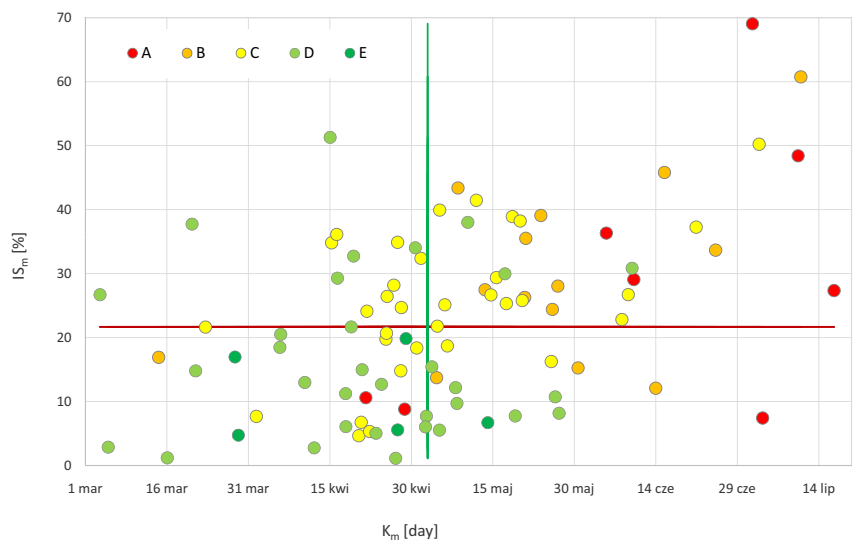

Figure 3. Seasonality index $\left(I S_{m}\right)$ and date of discharge concentration $\left(K_{m}\right)$ according to height of the springs (in meters a.s.l.): A - over 1000, B - 1000-750, C - 750-500, D - 500-250, $E$ less than 250. The lines indicate mean values (median).

An important indicator of the origin of the outflowing water is its temperature (Anderson 2005), especially in the springs supplied with water from rock glaciers (Zuecco et al. 2012). The temperature of water in the Gollinger Waterfall is low and relatively constant within the range of $5.1-6.4^{\circ} \mathrm{C}$. On the other hand, the correlations between seasonality parameters in the group of fissure springs are weak $(r=0.22)$ and statistically insignificant.

Domination of the nival type of supply caused us to investigate the extent to which seasonality parameters are affected by the geographical location of the outflows. Latitude and longitude coordinates determine, to some extent, the thickness and duration of a snow cover. However, the resulting correlation coefficients indicate that none of the variability and seasonality parameters are correlated with longitude. What is more, they are also independent of latitude, except for the discharge concentration date $(r=-0.44)$. The negative sign shows that the further to the north, and thus the lower the altitude, the earlier the date of the discharge concentration.

This seems to indicate that seasonality parameters may be related to the altitude of a specific outflow. The analyzed springs were classified into 5 altitude ranges. Figure 3 shows that the seasonality index of the lowermost springs $(<250 \mathrm{~m}$ a.s.l.) is lower than the average, as is the time of concentration, which occurs between the end of March and the first half of May. In contrast, the springs located at altitudes between 1000 and $750 \mathrm{~m}$ a.s.l. have very diverse seasonality 


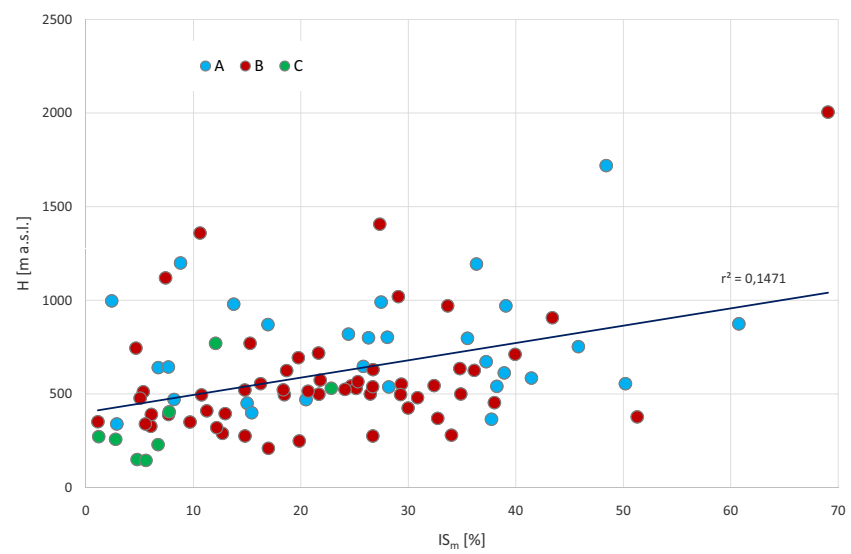

Figure 4. Seasonality index $\left(I S_{m}\right)$ and height of the outflows $(H)$ according to the spring hydrogeological type: $A$ - karst, $B$ - fissure, $C$ - porous. The line indicate significant trend.

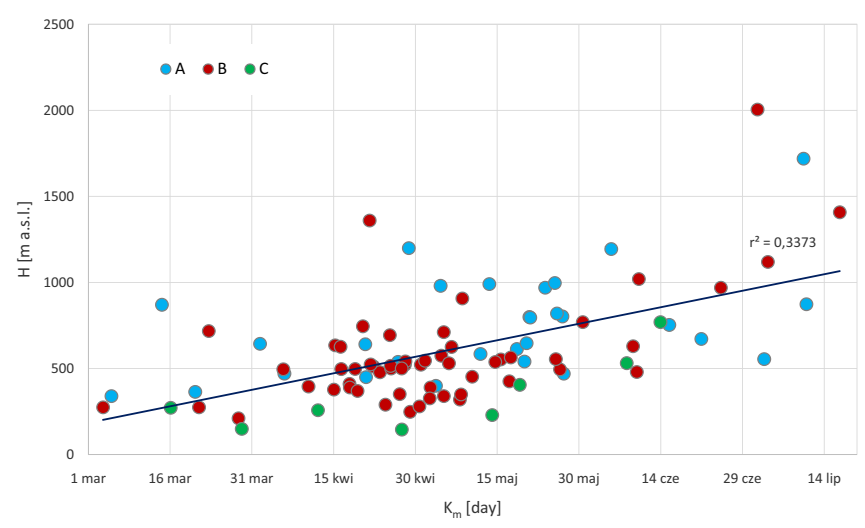

Figure 5. Date of discharge concentration $\left(K_{m}\right)$ and height of the outflows $(\mathrm{H})$ according to the spring hydrogeological type: $A$ - karst, $B$ - fissure, $C$ - porous. The line indicate significant trend.

indexes ( $\mathrm{IS}_{\mathrm{m}}=2.4-60.8 \%$ ), but, with the exception of the karst spring at Katzensteigquelle $\left(\mathrm{Q}_{\mathrm{m}}=134.3 \mathrm{dm}^{3} \cdot \mathrm{s}^{-1} ; \mathrm{K}_{\mathrm{m}}=\right.$ March 14th), their discharge concentrations occur later than usual - from May until the first half of July. This is similar to the highest outflows (>1000 m a.s.l.), where the discharge concentration usually occurs in June or July. Exceptions include two springs with relatively low seasonality index: a karst spring at Schwarzbodenquelle $\left(\mathrm{Q}_{\mathrm{m}}=23.5 \mathrm{dm}^{3} \cdot \mathrm{s}^{-1}\right)$ and fissure spring at Reihbachquelle $\left(\mathrm{Q}_{\mathrm{m}}=19.2 \mathrm{dm}^{3} \cdot \mathrm{s}^{-1}\right)$, the discharge concentration times of which occur in the third week of April.

The described situation is confirmed by the relationships, observed in the entire investigated spring population, between the index of seasonality and the outflow ordinate (Figure 4) and between the time of discharge concentration and the spring height (Figure 5). The calculated correlation coefficients are statistically significant for $\mathrm{p}=0.05$, and they amount to $\mathrm{r}=0.38$ and $\mathrm{r}=0.58$, respectively. The parameters of seasonal discharge are most strongly related to the altitude in the case of porous springs, and least strongly in the karst springs.

A significant relationship also occurs between outflow discharge and its altitude above sea level. It might be expected that spring discharges should increase with decreasing height, as the supply zone enlarges. Surprisingly, the correlation coefficient is positive and amounts to $r=0.62$. It should be noted, however, that most of the large karst springs are located in the Alps and this directly affects the results. For the same reason, the correlation coefficient between the outflow height and variability of its discharge, measured by means of the Maillete variability index, proved to be significant $(\mathrm{r}=0.45)$. These correlations were not observed for certain types of hydrological outflows, and thus they should not be taken into account. A weak correlation between discharge and height was observed only in the group of fissure springs $(\mathrm{r}=0.31)$.

\section{Conclusion}

For a majority of springs in the Central Europe, winter is an essential period of groundwater recharge, but summer rainfalls also play a key role in supply to springs. A prevalence of nival-pluvial regime is demonstrated by the time of discharge concentration that falls between early March and mid-July. In the karst springs, characterized by higher seasonal discharge, it occurs on average about three weeks later than in the fissure springs. The seasonality index of the porous outflows is several times lower, and the discharge concentration time occurs in the beginning of May. The outflow height was also found to be significant - the discharge of higher located springs is characterized by greater seasonal variability and a later concentration date. The study conclusions confirm the usefulness of the applied seasonality parameters in the analysis of the time series of spring discharges but also indicates the need for further research in this area.

\section{References}

Anderson, M. P., 2005, Heat as a Ground Water Tracer: Ground Water, v. 43, no. 6, pp. $951-968$.

Bard, A., Renard, B., Lang, M., 2011, Observed trends in the hydrologic regimes of Alpine catchments: International Closing Conference July 6th 2011 Munich (www.adaptalp.org/index.php?option=com_docman\& task $=$ doc_download $\&$ gid $=360 \&$ Itemid $=79$ )

Barczyk, G., 2003, Karst and vaucluse springs from the polish Tatra Mts. Results of long-term stationary investigations: Acta Carsologica, v. 32/ 1 , no. 11 , pp. $145-155$.

Birk, S., Wagner, T., 2011, New directions in the application of hydrograph recession models to karst aquifers: IAMG, 5-9 september, Salzburg (http:/ /www.cogeo.at/publications/iamg2011/IAMG2011_Salzburg_261.pdf)

Chelmicki, W., Jokiel, P., Michalczyk, Z., Moniewski, P., 2011, Distribution, discharge and regional characteristics of springs in Poland: Episodes, v. 34 , no. 4 , pp. $244-256$.

Christe, P., 2013, Climatic dependency of mountain springs: challenges for a sustainable groundwater management in the (Swiss) Alps: EFG Workshop 22-23 November, Brussels (http://www.eurogeologists.de/images/content/ Workshops/Hydrogeology/Christe_EFG\%20Workshop_20131123.pdf)

Dolezal, F., Kvitek, T., 2004, The role of recharge zones, discharge zones, springs and tile drainage systems in peneplains of Central European highlands with regard to water quality generation processes: Phys. Chem. Earth, v. 29, pp. 775-785.

Eybl, J. eds, 2005, Quellbeobachtung im Hydrographischen Dienst in Österreich. Mitteilungen des Hydrographischen Zentralbüros: v. 70, Wien, Annex part 1 and 2.

Eybl, J., eds., 2009, Richtlinie für die Errichtung und Beobachtung von Quellmessstellen in Österreich: Lebenministerium, Wien, pp. 1-132.

Fedorco, S., 2007, Rezim pramenov severnej casti Slanskych Vrchov a jeho ovplyvnenie klimatickou zmenou: University of Komensky, Bratistava (http://www.hydrogeology.sk/page.php?24).

Heinz, B., Birk, S., Liedl, R., Geyer, T., Straub, K.L., Bester, K., Kappler, A., 2006, Vulnerability of a Karst Spring to Wastewater Infiltration (Gallusquelle, Southwest Germany): Austrian Journal of Earth Sciences, v. 99 , pp. 11-17. 
Hilberg, S., 2010, Investigations of the aquifer characteristics of the dolomite formation on the Northern Calcareous Alps in Germany and Austria, in: Zuber A., Kania J., Kmiecik E. eds, XXXVIII IAH Congress "Groundwater Quality Sustainability Krakow”, 12-17 September 2010, Extended Abstracts, University of Silesia Press, pp. 1351-1360.

Hydrogeological Annual Reports 2003-2011: Polish Hydrogeological Survey, Warsaw.

Hydrological Yearbook of the Czech Republic 2004-2011: Czech Hydrometeorological Institute, Prague.

Kaiser, K., 2005, Die Teufelskirche (Vorderer Rettenbach), in: Eybl J. eds, Quellbeobachtung im Hydrographischen Dienst in Österreich. Mitteilungen des Hydrographischen Zentralbüros, v. 70, Wien, pp. 3437.

Kresic, N., Stefanowic, Z., 2009, Groundwater Hydrology of Springs: Butterworth-Heinemann, pp. 1-592.

Kresic, N., 2007. Hydrogeology and Groundwater Modeling, Second Edition: CRC Press, Taylor \& Francis Group, Boca Raton, Florida, pp. 1-807.

Kriz, H, 1973, Processing of Results of Observations of Spring Discharge. Ground Water, v. 11, no. 5, pp. 1-14.

Mair, G., 2005, Die Katzensteigquellen (Kasbachquellen), in: Eybl J. eds, Quellbeobachtung im Hydrographischen Dienst in Österreich. Mitteilungen des Hydrographischen Zentralbüros, v. 70, Wien, pp. 5458 .

Markham, C. G., 1970, Seasonality of precipitation in The United States: Ann. Assoc. Am. Geographers, v. 60, no. 3, pp. 593-597.

Manga, M., 1999, On the timescales characterizing groundwater discharge at springs: J. Hydrol., v. 219, pp. 56-69.

Milanovic, P., 2002, The environmental impacts of human activities and engineering constructions in karst regions: Episodes, v. 25, no. 1, pp. 13-21.

Pfleiderer, S., Klein, P., Reitner, H., Heinrich, M., 2006, The Hydrogeology of the Northern Calcareous Alps between the Rivers Enns and Ybbs: Austrian Journal of Earth Sciences, v. 99, pp. 4-10.

Plan, L., Kuschnig G., Stadler, H., 2010, Case Study: Kläffer Spring - the major spring of the Vienna water supply (Austria), in: Kresic N., Stefanovic Z., eds, Groundwater hydrology of springs: ButterworthHeinemann, Elsevier, pp. 411-427.

Pulido-Bosch, A., Padilla, A., Dimitrov, D., Machkova, M., 1995, The discharge variability of some karst springs in Bulgaria studied by time series analysis: Journal des Sciences Hydrologiques, v. 40, no. 4, pp. 517-532.

Rank, D., Wieselthaler, F., Papesch, W., Kuschnig, G., 2006, Separation of discharge components at a karst spring on the basis of event investigations (Wasseralmquelle, Austria): Austrian Journal of Earth Sciences, v. 99. pp. 18-23.

Rudolf, B., Rapp, J., 2003, The Century Flood of the River Elbe in August 2002: Synoptic Weather Development and Climatological Aspects Quarterly Report of the German NWP-System of the Deutscher Wetterdienst, no. 2, part 1, pp. 8-23.

Zuecco, G., Penna, D., Carturan, L., Seppi, R., Mantese, N., Gobbi, A., Zanoner, T., Gabrieli, J., Carton, A., Borga, M., Dalla Fontana, G., 2012, Origin of surface and subsurface waters in a periglacial catchment analysed by means of environmental tracers (abs.): Geophysical Research Abstracts, v. 14, pp. 5738.

http://ehyd.gv.at/

http://www.gkd.bayern.de/grundwasser/karten/index.php?gknr=0\& thema $=\mathrm{gkd} \&$ rubrik $=$ grundwasser $\&$ produkt $=$ quelle

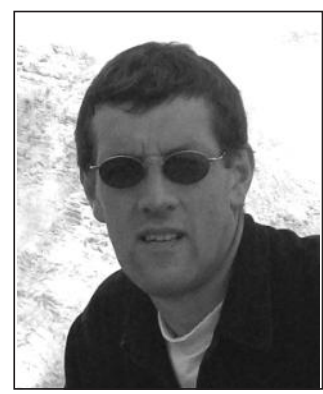

Piotr Moniewski - Researcher at the Department of Hydrology and Water Management, Institute of Earth Sciences, University of Lodz, Poland. His interests focus on groundwater outflows, water resources and hydrological measurement techniques, and human impact on water quality in rural and urbanized drainage basins. 